\title{
The Recent Decisions of the Turkish Council of Higher Education on Predatory Journals
}

The open access model, which emerged in the first years of this century and where authors pay publishers for their services, provides fast access to scientific information and data. With this new model, great changes were observed in the publishing industry. However, some publishers were quick to take advantage of some of its aspects and began publishing scientific articles without a real peer-review process. In 2010, Jeffrey Beall called this unethical publishing "predatory open access publishing" and has developed a blacklist of "predatory publishers and journals (Beall's list)".'

Publications on predatory publishing have been seen since $2014 .^{2,3}$ However, we had to wait a few more years to see its data from Turkey and Turkish scientists. As stated in the recent articles examine the Beall's list, Turkey is among the top three countries in the world in terms of the number of journals, publications, and editors. ${ }^{4-6}$

As Demir stated in his article, the academic incentive system of the Turkish Council of Higher Education (TCHE), which has been in effect since 2016, is one of the factors that encourage predatory journal publication. Since then, a significant increase has been seen in the number of published TR-addressed articles in predatory journals and presented at dubious conferences. ${ }^{6}$ More striking data about Turkish scientists was reported by Tonta et al. ${ }^{7}$ More than $80 \%$ of subsidies given to articles in the field of anthropology in 2015 went to a single predatory journal in this field, and Turkish researchers published a total of 127 articles, of which the majority was unrelated to anthropology.

Explaining Turkey's bad reputation only with the incentive system is incomprehensible. In our opinion, the more important factor is that quantity is at the forefront in academic promotion and tenure. An analysis by Akcigit revealed that researchers focused on lowerquality journals to meet the minimum publication criteria required for promotion and tenure. ${ }^{8}$ The TCHE has taken two important decisions in recent years to correct Turkey's bad reputation and discourage scientists from publishing in these predatory journals (Table 1). ${ }^{9}{ }^{10}$ These decisions may seem principally appropriate; however, they can lead to some negative consequences. In some cases, legitimate journals may even run the risk of being labeled as predatory.

Several issues are thought to confuse these decisions, thus should be discussed in detail. Herein, some confusing issues are pointed out.
According to the decision of TCHE in 2021, a journal that charges for publication fee in the Q4 will be classified as predatory if it is published by a private publisher or non-public association. Thus, many legitimate journals will be at risk to be labeled as predatory or questionable. Furthermore, the exact meaning of the definition of "scientific institution" other than university and institute is unclear. Thus, this type of journal has to be subscription journals and started a publication life earlier than 2010 to not be classified as predatory.

Asking the following questions about this situation is inevitable: 1) the status of legitimate journals published by a private publisher (Elsevier, Springer, etc.) and 2) the status of subscription journals that started broadcasting after 2010. Therefore, such a decision exposes many private publishers and non-public association journals to unethical publishing charges.

The decision that only subscription journals published before 2010 are considered legitimate places dozens of open access legitimate journals that started their publication life before 2010 under suspicion. Meanwhile, this predatory publishing activity is known to have started before $2010{ }^{1}$

Journals indexed in the SCI-Expanded (Web of Science) are thought to be one of the most reliable journals for ethical publishing. A conducted study supports this assertion. Demir aimed to investigate whether indices (e.g., SSCI/ SCI/AHCI/ESCI, SCOPUS, MEDLINE, HW Wilson, ERIC) include potentially predatory or fake journals that are identified earlier in Beall's list (2708 journals). Fourteen indices were examined and revealed that the most reliable indexes include SCI-Expanded (only one journal in Beall's list) and the ESCI (only two journals in Beall's list). For MedLine and Scopus, 6 and 53 journals were found in Beall's list, respectively. ${ }^{11}$

Publishers generally do not demand money from the author before the manuscript acceptance. The real problem is not the demand for money, but its transparency. If this situation is clearly stated in the information section to the authors and the journal seriously carries out the peer-review processes and within ethical limits, it is not an ethical problem to demand money for publication. This open access system has emerged to circumvent the limitations of the subscription system and this money must be provided by the author or otherwise to maintain this fast and open publishing.

In our previous articles, our views on predatory journals and conferences and the necessary precautions were expressed. ${ }^{12,13}$

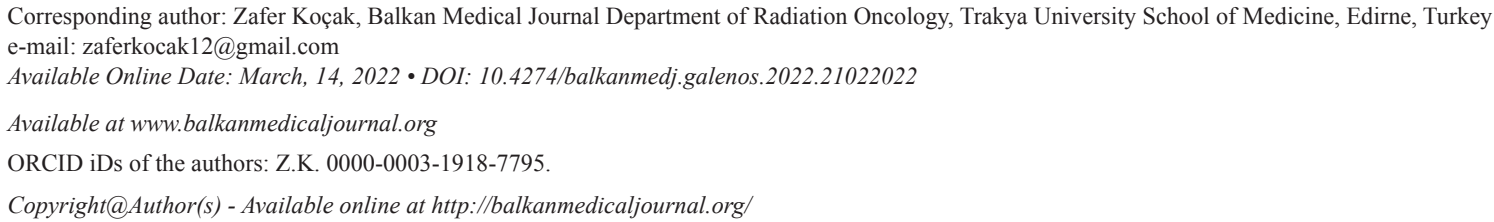


TABLE 1. Recent Decisions of the Turkish Council of Higher Education on Predatory/Questionable Journals

The Decision of the Turkish Council of Higher Education dated March 07, 2019, on Predatory/Questionable Journals

$>$ Journals that demand a fee or additional fee from the author for publication after the manuscript acceptance (Predatory Journals) cannot be used in the associate professorship application (declaration) since this relationship contains a conflict of interest. However, it should be added to the CV and the list of publications.

$>$ Therefore, the following journals can be used in the associate professorship application (declaration):

- Journals that charge a fee upon article submission, regardless of the acceptance/rejection status,

- Journals that charge a fee to make the relevant article open access although it works on a subscription basis,

- Journals that do not charge any fee from the authors during the article publication process.

- Although the journal, in which the article declared in the application was published, formally complies with the above-mentioned "journals that cannot be used in the declaration," candidates claiming that the relevant journal should not be evaluated within this scope can declare the relevant article by stating their justification.
The Decision of the Turkish Council of Higher Education dated December 30, 2021, on Predatory/Questionable Journals

$>$ Journals that are not considered predatory:

- Journals classified as Q1, Q2, and Q3 in Web of Science (with or without charge for editorial and/or publication processes),

- Journals classified as Q4 in Web of Science without charge for editorial and/or publication processes),

- Journals classified as Q4 in Web of Science with a charge for editorial and/or publication processes must have the following features:

- The publication organ of a branch association, university, or scientific institution to which only members of the relevant branch of science can become members, and

- Published as a subscription journal since 2010

$>$ Predatory Journals: Q4 journals that do not meet the above-mentioned criteria

$>$ Following the decision taken at the General Assembly of the Turkish Council of Higher Education dated 07.03.2019, to be valid for the published articles after 07.03.2019. Journals that charge a fee or additional fee from the author for manuscript publishing after its acceptance (Predatory journals) cannot be used in applications for associate professorship (declaration) since this relationship contains a conflict of interest.

There is no globally accepted list of predatory journals and dubious conferences and this is a dynamic process, thus such decisions must be carefully made and implemented. Who decides whether a journal is predatory, for example, the academic assessment committee, editors, authors, institutions, etc. It may be more logical and fair to specify what is good or reliable (whitelist: DOAJ, Science Citation Index, MEDLINE, etc.) rather than bad or unreliable (blacklist).

For such decisions to serve the right purpose, they must be applicable, clear, and fair. It would be fair to state that the old and new regulation of TCHE is unclear enough and causes various interpretations. Therefore, a new regulation is needed, and including common stakeholders in the decisions for measures to prevent scientists from submitting their studies to these predatory journals would be appropriate. The first step can be taken by describing legitimate journals.

\section{Zafer Koçak}

Editor in Chief, Balkan Medical Journal Department of Radiation Oncology, Trakya University School of Medicine, Edirne, Turkey

\section{REFERENCES}

1. Beall J. Predatory publishers are corrupting open access. Nature. 2012;489:179. [CrossRef]

2. Xia J, Harmon J, Connolly K, Donnelly R, Anderson M, Howard H. Whopublishes in predatory journals. JASIST. 2014;1406-1417. [CrossRef]
3. Shen $\mathrm{C}$ and Björk BC. "Predatory" open access: A longitudinal study of article volumes and market characteristics. BMC Medicine. 2015;13:230. [CrossRef]

4. Demir SB. Predatory journals: Who publishes in them and why? Journal of Informetrics. 2018;12:1296-1311. [CrossRef]

5. Akça S, Akbulut M. Predatory Journals in Turkey: An Investigation Through Beall List. Bilgi Dünyası. 2018;19:255-274. [CrossRef]

6. Demir SB. Pros and cons of the new financial support policy for Turkish researchers Scientometrics. 2018;116:2053-2068. [CrossRef]

7. Tonta Y (2017b). TÜBİTAK Türkiye Adresli Uluslararası Bilimsel Yayınları Teşvik (UBYT) Programının değerlendirilmesi. Ankara: TÜBİTAK ULAKBİM (Accessed September 16, 2019). from http://ulakbim.tubitak.gov.tr/sites/images/Ulakbim/tonta ubyt.pdf.

8. Akciğit U (2020). Ağustos. Regülasyonlar ve akademik yayınlar (blog yazısı). from https://www.artnotlari.com/blog/akademik-yayinlar (Accessed February 18, 2022), 24:Art Notları. [CrossRef]

9. The Turkish Council of Higher Education Decision on predatory journals (Date: March 7, 2019). from https://www.uak.gov.tr/DuyuruBelgeleri/gecmis-duyurular/2019mart-donemi/2019E_Duyuru_YÖK\%20Karar1_140319.pdf (Accessed February 18, 2022). [CrossRef]

10. The Turkish Council of Higher Education Decision on predatory journals (Date: December 30, 2021, and No: 2021.18.643). from https://www.uak.gov.tr/ DuyuruBelgeleri/2022/yagmac1-saibeli-dergiler-hk-duyuru-25012022.pdf (Accessed February 18, 2022). [CrossRef]

11. Demir SB. Scholarly databases under scrutiny. Journal of Librarianship and Information Science. 2020;52:150-160. [CrossRef]

12. Koçak Z. Predatory Publishing and Turkey. Balkan Medical Journal 2019;36:199 201. [CrossRef]

13. Koçak Z. Precise and Immediate Action against Predatory Conferences. Balkan Med J. 2020;37:1-2. [CrossRef] 